\title{
VAN DIE REDAKSIE.
}

\section{„Woord en Daad".}

Van harte verwelkom ,Koers" sy jong boetie „Woord en Daad" wat nou net die lewenslig aanskou het.

Waar ,Koers" as leserskring hulle het wat in populêr-wetenskaplike en wetenskaplike leesstof belangstel en wat publikasie op hierdie gebied wil ondersteun en bevorder, daar rig "Woord en Daad" sig tot almal en meld dit hom aan as maandblad vir die Christelike gesin.

Beide stem egter daarin ooreen dat hulle Calvinistiese tydskrifte is en die lig van Gods Woord op alle lewensterreine wil laat val.

„Woord en Daad wil probeer om ' $n$ eie plek in $u$ hart en huis te verower..... Dit beweeg sig op die terrein van die maatskappy .... Dit wil op alle terreine vraagstukke laat sien in die lig van God........Dit wil Christelik-nasionaal wees en republikeins........volgens die wortel van ons volkshistorie........Dit wil iets vir elke gesin gee, selfs vir die heel kleintjies ........Dit sal nie gee sensasie, seks, en sentiment, halfnaakte vroue, verslae oor vuil hofsake, toertjies van die Folies Bergères, verslae van stoei- en bokstoernooie, die doen en late van sterre van Hollywood, ens. nie...... Inteendeel wil dit ons volk ophef tot 'n hoër plan."-Dit is enkele grepe uit die Redaksiewoord.

„Ons_en dan bedoel ek Calviniste-moet'n tydskrif kry wat aan die oortuigde Calvinis leiding kan gee, 'n leiding wat pylreguit, konsekwent, doelgerig en beginselvas is. So 'n tydskrif is 'n moet!' So skryf die Rektor van ons Universiteit, prof. dr. J. Chris Coetzee in hierdie blad.

„Calviniste, hul soüt werd, moet'n eie mondstuk he; hulle eie taal praat; hulle eie gedagtes laat hoor; hulle eie roeping in die pers-wêreld verval.......in opdrag van sy Meester: julle sal my getuie wees in Jerusalem ........tot aan die uiterste van die aarde". So skryf ds. I. D. Krüger, die voorsitter van die Kuratorium van die Teologiese Skool, Potchefstroom.

„Dit het tyd geword dat ons volk in al sy geleidinge die betekenis van 
die Calvinistiese lewens- en wêreldbeskouing in sy diepgang maar ook in sy volle draagwydte beter sal leer verstaan". So skryf prof. dr. F. J. M. Potgieter van die Teologiese Seminarium, Stellenbosch.

„Ek is so dankbaar vir hierdie publikasie waarvan ons met reg mag verwag dat dit met eerbiediging van die ordinansies van God, op ons Afrikaanse tradisies sal voortbou". So skryf ds. D. F. Erasmus van die Hervormde Kerk.

„Woord en Daad" sal sodanig wees dat elkeen dit sal kan verstaan Dit sal vraakstukke van allerlei aard bespreek en in verband daarmee prinsipiële voorligting gee." So skryf prof. dr. J. C. van Rooy, Kanselier van ons Universiteit.

„Ons hoop dat „Woord en Daad" met sy Christelike en Calvinistiese grondslag, sy deel sal bydra om te herstel wat reeds beskadig is en om te behou wat nog ongeskonde in ons Volksteater en sedes is". So skryf sy edele, minister J. G. Strydom.

Bostaande grepe uit die welkomswoorde van genoemde persone er: uit die Redaksionele woord, die geesdrif en besieling wat uit al dié stukke straal, die verwagtinge wat in dié getuienisse aangaande hierdie eersteling gekoester word-dit alles onderskryf „Koers" van harte.

„Woord en Daad" vul'n plek in ons samelewing wat.al veels te lank leeg gestaan het. Ons volk het op alle lewensterreine en in al sy groot vraagstukke Calvinistiese leiding so besonder nodig dat ons ons afvra hoe ons in die verlede sonder sö'n tydskrif kon klaargekom het. Maar uit hierdie woorde blyk dan ook die sware verpligting en ernstige verantwoordelikheid wat op "Woord en Daad" rus, nl. om die Waarheid bo die lewe, beginsels bo persoonlike belange te stel en waar nodig-al is dit met die vereiste takt on diskresie-ons eie mense waar hulle van die weg van die vaders afwyk, te waarsku en te vermaan.

"Woord en Daad" het gekom om te bly. Hy sal in stand gehou word desnoods met finansiële offers van hulle wat hierdie tydskrif op hul harte dra, net soos „Koers" deur sy lede en donasies van die Raad van ons Universiteit gedra word. Maar mag dit anders met "Woord en Daad" gaan, mag sy intekenaretal en advertensies so styg dat "Woord en Daad" nie net selfbetalend is nie, maar binne kort tot'n weekblad omgevorm kan word! 
"Koers" wens die Afrikaanse Calvinistiese Beweging wat die uitgawe van hierdie tydskrif onderneem alle sukses toe en wens "Woord en Daad" 'n geseënde en invloedryke en lange toekoms toe!

Teken in op „Wood en Daad", Posbus 11, Noordbrug, Potchefstroom teen die veels te laag gestelde bedrag van 6/-per jaar-nie net om wat hierdie tydskrif vir u sal beteken nie, maar ook om dit te help om sy plek in ons samelewing vol te staan en sy roeping met eer te kan vervul!

\section{DIE GEREFORMEERDE VAANDEL.}

Die Trustees van „Die Gereformeerde Vaandel” kondig in sy jongste uitgawe o.a. aan dat SACUM Bpk. voortaan die administrasie van die blad sal behartig; dat die blad tans 'n streng wetenskaplike kwartaalblad sal word, dat drie van die uitgawes aan die verskillende vertakkings van dic teologie gewy sal word en een aan die uitbou van die Christelike wysbegeerte, wetenskap en kuns met dien verstande dat wanneer nodig die genoemle verhouding gew.ysig kan word; en dat prof. dr. E. P. Groenewald van die U.P. tot die redaksie toetree. *

Hierdie tydskrif bestaan al 22 jaar en is tydens die spanninge binne die Ned. Ger. Kerk oor die standpunt van prof. J. du Plessis in die lewe geroep en wel as 'n Calvinistiese getuienis vir die suiwere leer van ons geloof. In die 22 jaar het hierdie blad naam gemaak. Besonder waardevolle artikels het daarin verskyn.

„Koers” wil sy Calvinistiese kollega, „Die Gereformeerde Vaandel”, in sy nuwe ontwikkeling van harte die ryke seën van God toebid en vertrou dat hy nog vir baie jare sy invloed in ons land sal laat geld. Mag sy ideaal om tot eer van God die teologiese wetenskap te help uitbou ruimskoots verwesenlik word.

* Dic ander redaksielede is Prof. dr. F. J. M. Potgieter, prof. dr. J. J. Muller, prof. dr. P. A. Verhoef (al drie van Stellenbosch), prof. dr. E. A. Venter (Bloemfontein) en ds. J. D. Vorster (Kaapstad). 